Universitäten und zum organisatorischen Aufbau sowie der finanziellen Unterstützung der Studenten und Praktikanten insbesondere in Lagos fehlen völlig.

Interessant ist der Beitrag von Abdur Rahman I Doi "The Impact of English Law Concepts on the Administration of Islamic Law in Nigeria". Doi stellt nicht nur den historischen Wandel des islamischen Rechts unter der Kolonialherrschaft, sondern auch nach der Unabhängigkeit dar. Beiden historischen Phasen ist das Bestreben der jeweiligen Regierung gemein, das islamische Recht in seiner Anwendung zurückzudrängen, obgleich ihm insbesondere im Personenstandsrecht auch heute noch eine bedeutende Funktion bei der Befriedung sozialer Konflikte zukommt. Noch 1975 wurde von der von General Murtala Mohammed eingesetzten Kommission festgestellt, daß im Norden Nigerias $94 \%$ aller Rechtsfälle von den "Native Courts" und nur $6 \%$ von den "Magistrates and High Courts" entschieden werden (S. 34).

Die sozialen Widersprüche in der Handhabung traditionellen Rechts werden bei $B . A$. Rwezaura "The Changing Role of the Extended Familiy in Providing Economic Support for an Individual in Africa" offenbar. Ebenso wie Doi weist Rwezaura auf den sozialen Wandel, der die Anwendung traditionellen Rechts mehr denn je in Frage stellt hin. Dabei wird dessen Funktion keinesfalls verklärt, sondem auch die Gefahr einer Benachteiligung einzelner Bevölkerungsgruppen, insbesondere der Frauen, hervorgehoben. Die Darstellung verschiedener Gerichtsurteile belegt, daß auch die Rechtsprechung bei der Anwendung traditionellen Rechts einen Wandel vollzieht und Benachteiligungen einzelner Bevölkerungsgruppen auszuschließen versucht.

Ulrich Werwigk

\title{
Comparative Study of Cooperative Law in Africa
}

A Six Country Report by Marburg Consult for Self-help Promotion.

Published by Marburg Consult, 670 pp., DM 48,--

Cooperative Law in Africa is one area of the law which does not interest lawyers very much, perhaps because it deals with rural inhabitants with whom lawyers are not usually in touch. And yet, cooperatives have existed in Africa, in one form or another, for centuries. This publication is, therefore, a welcome incentive to lawyers willing to take a new look at the subject.

The book is a compendium of studies carried out in six African countries, Burkina Faso, Ghana, Ivory Coast, Nigeria, Senegal and Tanzania. All contributors are indigenous to the countries they studied. The stated aim of the study is to "... meet urgent research needs in the fields of development theory and policy and cooperative law". Sponsors of the study recognise that, with a realistic approach to rural development would seem to be the promo- 
tion of self-help organisations. Hence, a comprehensive study of the law governing cooperatives is necessary.

The countries covered in this study fall into two groups: Anglophone and Francophone. Of the two groups, it is that of the Anglophone countries which have a longer tradition of cooperative legislation, going back to the colonial days, when British Indian cooperative legislation was introduced to Africa; to the Gold Coast (Ghana) in 1931, to Tanganyika (Tanzania) in 1932 and to Nigeria in 1935. The reasons for the transfer of legislation from Asia to Africa was summarised in Strickland's book, Cooperation for Africa, Africans would need cooperative law "... framed from a standpoint of a progressive administrator". The approach illustrates the British concept of "indirect rule", whereby the colonised people were allowed to retain as much of their own administrative structures as possible.

In the French colonies of Africa, however, the policy was to replace indigenous administrative structures with French colonial institutions. Thus the district of ficers (commandants de cercles) were in charge of district cooperatives and not local officials. This is the more striking as cooperatives were known to Africa long before the colonial era.

The book deals with African indigenous cooperatives but does not treat them in detail. This is a pity as these cooperatives continue to exist in large numbers, not only in rural areas but also in the cities. There are various types of traditional cooperatives based on lineage, class or cast, age and profession such as fishermen, carvers, iron mongers etc. Thus, there is the naam in Burkina Faso, tong in Mali, the nnoboa and the esusu in Ghana and the fonkonolona in Madagascar to mention but a few. Possibly one cannot blame the authors for this omission as African governments themselves fail to recognize indigenous cooperatives as engines of development. On the contrary, African governments have chosen to encourage the development of European-type cooperatives, in the hope that these will accelarate development. While this may be the case, it is still no reason to completely neglect indigenous cooperatives.

What becomes abundantly clear in the book is that, African govemments believe they can use the cooperative movement as a means of development. This policy has received the support of some academics, such as Eugen Schaeffer, sometime professor of law at the University of Dakar. He compares legislation in industrialised countries to that in developing countries and comes to the conclusion that legislation in developed countries does not seek to change existing structures or mentality. Here, the law preserves rather than changes. In developing countries, on the other hand, the law seeks to destroy the existing structures and build new ones. Professor Schaeffer refers to this type of legislation as "Law of Development".

Whether one agrees with Schaeffer's theory or not, African governments have sought to apply cooperative legislation as an engine of change. How successful this process has been is controversial. Legislation by itself is unlikely to bring about change without the right economic and social atmosphere. For European-type of cooperatives to succeed, there must be sufficient funding, high levels of education, markets for goods produced and independence from government control. These conditions are visibly lacking in Africa. 
The unfortunate conclusion to be drawn is that African cooperative movements are various stages of decline rather than growth. "Il n'est personne aujourd'hui pour douter que le mouvement coopératif sénégalais ne soit gravement malade", was said of the movement in Senegal, but it applies equally today to all other African countries.

E.K.M. Yakpo

\author{
K. Ferdinand / M. Mozaffari \\ Islam: State and Society \\ Hrsg. vom Scandinavian Institute of Asian Studies \\ Curzon Press Ltd., London 1988, 219 S.
}

Das Buch enthält die Beiträge zu einem Kongreß, der im Spätsommer 1984 an der Universität Aarhus zu dem Thema "Islam - Staat und Gesellschaft" stattfand. Es gibt die unterschiedlichsten Einblicke in das Staatswesen der islamischen Welt und zeigt u.a. die gesellschaftspolitischen Probleme auf, die diesen Staaten heute bei der Bewältigung, Umsetzung oder auch Loslösung von der Maxime "la din - la dawla" (ohne Religion gibt es kein Gemeinwesen) erwachsen.

Teil I befaßt sich mit zeitgenössischen Islamstudien. Während Chr. Toll Ziel und Zweck derartiger Studien erörtert und auch einen historischen Rückblick auf die europäische Orientforschung nicht ausläßt, gibt der anschließende Beitrag von J. Hjärpe die - weitaus aktuellere - Debatte in der islamischen Welt über die in der UN-Deklaration von 1948 verankerten Menschenrechte wieder. Hjärpe schildert deutlich, warum Akzeptanz und Ablehnung der UN-Deklaration oft dicht beieinander liegen und bis heute nicht einmal über den Begriff der Menschenrechte Einigkeit erzielt werden konnte: Die UN-Deklaration als von Menschen geschaffenes Recht muß im islamischen Verständnis zwangsläufig gegenüber der Sari'a als göttlichem und alles beherrschendem Recht mängelbehaftet, lückenhaft und generell minderwertig sein mit der Folge, daß Menschenrechte, deren Verständnis im Gegensatz zur Sari'a steht, nicht als solche gelten. Nur folgerichtig war der - in Europa wenig beachtete - Entwurf einer Menschenrechtsdeklaration auf der 14. Islamischen Konferenz in Dhaka 1983, deren wichtigste Punkte Hjärpe skizziert. Kerimov befaßt sich mit islamischer Missionstätigkeit und schildert die Rolle islamischer Zentren in Europa als Kultur-Mittler, auf die insbesondere die islamische Minderheit in der Diaspora angewiesen sei. Der von manchen dieser Zentren ausgehende Mißbrauch durch Förderung politischer Aktivitäten an der Grenze der Legalität wird totgeschwiegen bis auf einen Nebensatz "carrying out various political activities". Auch sonst begegnet der Beitrag von Kerimov erheblichen inhaltlichen Bedenken - oder sollte man angesichts der Beispiele im Sudan und Iran emstlich annehmen, daß durch die Verbreitung von Sari'a-Gerichten die Zahl der 